\section{Efficacy of an Organic Solvent and Ultrasound for Filling Material Removal}

Gabriela Guardiola Müller, Ânielle Pinheiro Schönhofen, Patrícia Maria Poli Kopper Móra, Fabiana Soares Grecca, Marcus Vinícius Reis Só, Augusto Bodanezi
Department of Conservative Dentistry, School of Dentistry, UFRGS Federal University of Rio Grande do Sul, Porto Alegre, RS, Brazil

Correspondence: Prof. Dr. Augusto Bodanezi, Rua Ramiro Barcelos, 2492, 90035-120 Porto Alegre, RS, Brasil. Tel: +55-51-3308-5430. e-mail: augusto.bodanezi@ufrgs.br

\begin{abstract}
The aim of this study was to investigate whether a final rinse with Endosolv $R^{\circledast}$ solvent and ultrasound resulted in cleaner root canal walls during endodontic retreatment. $A$ total of 56 extracted premolar teeth were manually instrumented using a step-back flare technique and filled with gutta-percha and AH Plus sealer. After 9 months, the canals were retreated by removing the gutta-percha and sealer with ProTaper Universal Retreatment and rotary preparation with ProTaper Universal System up to an F5 file. As a final step, the teeth were randomly divided in 4 groups $(n=14)$ and were subjected to passive ultrasonic irrigation (PUI) with either Endosolv R or distilled water. In the control groups, the irrigants were left undisturbed. Roots were cleaved and examined under scanning electron microscopy (SEM), and the amount of filling remnants on the canal walls was assessed by two calibrated examiners in a blinded fashion. Data were analyzed by the Kruskal-Wallis test and the Student-Newman-Keuls post hoc test $(\alpha=0.05)$. All groups presented filling debris in the three root canal thirds after retreatment. There were no significant differences between the groups or among the root canal thirds within each group ( $p>0.05$ ). PUI with Endosolv $R$ was not effective in the removal of filling debris from root canal walls.
\end{abstract}

Key Words: ultrasound, retreatment, solvents, therapeutics, root canal filling materials.

\section{Introduction}

Conventional endodontic retreatment is the primary choice to deal with residual or subsequently acquired infection after primary root canal therapy (1). To succeed in this procedure, the removal of as much as possible of sealer and gutta-percha from inadequately shaped and filled root canal system is critical for uncovering remnants of necrotic tissue or bacteria and to expose them to a more efficient chemo-mechanical disinfection protocol (2). Nevertheless, root filling removal from root canal irregularities, such as oval extensions, isthmuses and apical deltas, is a major concern due to inaccessibility of instruments and chemical irrigants (3). In an attempt to address this challenge, the additional enlargement of the root canal with extra NiTi rotary files has been proposed (4), but root canals that are completely free of filling residues have remained unattainable (4-8).

Passive ultrasonic irrigation (PUI) of $\mathrm{NaOCl}$ and EDTA have been proposed to improve root canal cleaning by the removal of organic tissue remnants, dentin debris and microorganisms from root canal walls and anatomic areas that are difficult to access (1). The rapid and continuous movement of irrigants around the vibrating files seems to enhance the potential of the solution to contact a greater surface area of the canal wall and thus exert their chemical and physical properties (9). Additionally, the dislodged material may be detached from the root canal wall and absorbed or dissolved in the irrigant (10).
Organic solvents are a chemical class of compounds that are applied during retreatment to decrease the resistance of filling materials in the root canal (11), thus facilitating their removal without damaging the tooth (6). Diverse chemical solvents are available, and they dissolve root canal sealers at different intensities (11). Sometimes, these substances need to be renewed during filling removal so that the instruments may reach the apical foramen (12).

Endosolv $R$ is an organic solvent that has been shown to aid in fresh AH Plus removal after filling (13) and to dissolve set AH Plus in vitro better than orange oil and distilled water (14). As ultrasonic agitation might be beneficial for improving the chemical properties of organic solvents, such as their dissolving capacity, the aim of this study was to investigate whether PUI of Endosolv R as a final flush during retreatment results in cleaner root canal walls.

\section{Material and Methods}

This study was approved by the Dentistry Research Committee and by the Ethics Committee of Federal University of Rio Grande do Sul (Protocol \#18179/2011).

\section{Specimen Preparation}

Fifty-six extracted human mandibular premolars $(22 \pm 1 \mathrm{~mm})$ with single root canals were used in this study. Roots with severe curvatures $\left(>20^{\circ}\right)$, immature apices or previous root canal treatment were discarded. Soft tissue and calculus were mechanically removed from the root 
surfaces. After cavity access preparation, a size $10 \mathrm{~K}$-file was inserted to determine the patency of the root canal and to establish the working length of each tooth by subtracting $1 \mathrm{~mm}$ from the length at which the file tip could be viewed at the apical foramen. The canals were manually prepared with the Oregon technique (15) until a size $35 \mathrm{~K}$-file reached the apical length. Canals were irrigated with $1 \mathrm{~mL}$ of $2 \%$ sodium hypochlorite after each instrument change. After a 3-min final irrigation with 17\% EDTA followed by a final flush with $2 \mathrm{~mL}$ of $2 \%$ sodium hypochlorite, the canals were dried with sterile paper cones.

\section{Root Filling}

A standardized gutta-percha master cone (size 35) (Tanariman Industrial Ltda., Manaus, AM, Brazil) was fitted with tug-back at working length (WL). This master cone was lightly covered with AH Plus sealer (Dentsply De Trey, Konstanz, Baden-Württemberg, Germany) and slowly inserted into the root canal until it reached WL. Cold lateral compaction with accessory gutta-percha cones (fine medium size) was performed until the cones could not be introduced further than $5 \mathrm{~mm}$ into the root canal. The excess gutta-percha was removed with a heated plugger, cavities were sealed with ionomer (Vitremer; 3M/ESPE, St. Paul, MN, USA). Subsequently, the specimens were stored at $37^{\circ} \mathrm{C}$ and $100 \%$ humidity for 9 months.

\section{Retreatment Technique}

After the aging interval, root canal retreatment was performed with ProTaper Universal Retreatment (DentsplyMaillefer, Ballaigues, Switzerland) instruments at $500 \mathrm{rpm}$ and $3 \mathrm{~N} / \mathrm{cm}$ torque (8). The D1 ProTaper file (size 30, 0.09 taper) was used for the removal of the coronal third of the root canal filling, followed by the use of the D2 ProTaper instrument (size 25, 0.08 taper) for the middle third of the root canal. Finally, the D3 ProTaper instrument (size 20, 0.07 taper) was used at WL. From this phase on, irrigation started and distilled water was applied with a syringe and a 30-gauge needle after each instrument change. Apical preparation was performed with ProTaper instruments F2 (size 25, 0.08 taper), F3 (size 30, 0.09 taper), F4 (size 40, 0.06 taper) and F5 (size 50, 0.04 taper) at 250 rpm and 1.5 $\mathrm{N} / \mathrm{cm}$ torque. The same experienced operator, who received prior training, performed all retreatments. Procedural incidents, such as blockages and instrument fractures, were recorded. If an instrument fracture occurred, the specimen was replaced.
All instruments were discarded after use in six root canals. Retreatment was deemed complete when the last file reached $W L$, there was no filling material covering the instrument, and the canal walls were smooth and free of visible debris. Roots were fixed to the opening of an Eppendorf-type vial, and the sets were inserted into an acrylic resin base for stability.

Afterwards, the sample was divided into four groups of 14 teeth, and each group received a different final irrigation protocol. In the experimental groups, the root canals were flooded with formamide or distilled water, respectively, and an ultrasonic smooth wire (CVD Dentus; São José dos Campos, SP, Brazil) attached to an ultrasound device (NAC Plus; Adiel, Ribeirão Preto, SP, Brazil) was inserted $3 \mathrm{~mm}$ short of the root canal length and activated for 60 $\mathrm{s}$ at maximum intensity. The same procedures, excluding ultrasound activation, were conducted for the two control groups. No renewal of solutions was performed during or after ultrasound use. Finally, the root canals were irrigated with $3 \mathrm{~mL}$ of distilled water, dried with paper cones, and stored for $96 \mathrm{~h}$ at $20 \pm 3{ }^{\circ} \mathrm{C}$ for dehydration.

\section{SEM of Filling Debris}

The roots were grooved longitudinally in a buccolingual direction with a diamond disk and split into halves with a chisel. Both halves were viewed under a stereomicroscope (EMZ-TR, Meiji, Saitama, Japan) at 5.5x magnification, and the half with a greater amount of filling debris was examined with a scanning electron microscope (JSM6060; JEOL, Tokyo, Japan) at $75 \times$ magnification. One representative SEM micrograph was taken for each root canal third (coronal, middle and apical).

Prior to image assessment, two reviewers received instructions and were calibrated with 30 images presented on a projection screen. The 168 micrographs were numbered, mounted in random order, and individually categorized according to a grading system, which was used to score the amount of residual filling debris in each root canal section. The following criteria were used: $0=$ none to slight presence (0\%-25\%) of residual debris covering the dentinal surface, 1 $=$ presence of $25 \%$ to $50 \%$ of residual debris on the surface, $2=$ moderate presence $(50 \%-75 \%)$ of residual debris, and $3=$ the entire or almost the entire surface (75\%-100\%) is covered with residual debris. No attempt was made to distinguish between filling materials or sealer remnants. After four weeks, the image assessments were repeated for the estimation of intra- and inter-examiner agreement.

\section{Data Analysis}

Data were analyzed statistically with the Kruskal-Wallis test and the Student-Newman-Keuls post hoc test ( $\alpha=0.05$ ). First, statistics were used to compare canal thirds within 
each group; next, the groups were compared in each canal third; and finally, intergroup comparison considered the total canal area to calculate the filling debris.

\section{Results}

Table 1 presents the median and range of root canal wall scores obtained in the root canal thirds for each group. The differences within each group were not statistically significant (Table 1, Fig. 1). The techniques did not differ significantly when each third was compared between groups (Table 1, Fig. 1). The inter-examiner agreement value was 0.67 for the first assessment and 0.63 for the second. The intra-examiner agreement value was 0.81 for examiner \#1 and 0.89 for examiner \#2. No procedural errors were observed, but three ProTaper instruments (1 D3 and 2 F2) fractured.

\section{Discussion}

The main objective of nonsurgical retreatment is to remove all filling material from the root canal and to regain access to the apical foramen (6). In laboratory research, optical microscopy is still the most common method for obtaining information about dentin cleanliness after retreatment (7). Scanning electron microscopy, however, allows the examination of the entrance of dentinal tubules, where the process of hybridization and resin-tag formation of cements occurs (16). A disadvantage of this methodology is that only a very small part of the root canal can be evaluated, and it is often not standardized. In an attempt to address this bias, lower magnification than those presented by Somma et al. (7) was employed to increase the observation area and strict criteria for examiner calibration were also conducted. Nevertheless, despite these actions, variation between different observers, owing to the subjective evaluation of images, was still expected (17) and may also account for the lack of statistical significance that was observed between the groups.

Two recent investigations on straight root canals demonstrated that apical enlargement by two sizes beyond the initial preparation size significantly reduced the amount of residual filling material, but no complete removal occurred (4). In this study, despite apical enlargement with three instruments beyond the initial preparation size, the filling remnants were distributed equally in patches throughout the buccal and lingual walls, as observed for the experimental and the control groups, possibly due to the mesio-distal flattening of premolar teeth.

Optical microscopy and three-dimensional reconstruction studies revealed that filling removal with Protaper Universal NiTi System or ProTaper Universal Retreatment left more residual fillings in the apical third of root canals $(18,19)$. By contrast, in this study, no significant difference was observed between the cervical and apical thirds in all groups. The additional apical enlargement with ProTaper F5, however, might have caused the apical removal of debris to a level at which no significant difference was detected in relation to the cervical third, where the ProTaper Universal Retreatment D3 taper 0.07 instrument contacted a greater dentin surface area. The root canal filling may have been easier to remove from the apical third because no organic solvent was used during retreatment. Chemically softened fillings may be easily pushed into anatomically complex canal irregularities that have not been touched by rotary instruments $(6,7,17)$.

Through ultrasound activation, the irrigant was expected to penetrate more easily into the apical part of the root canal system (20), thus increasing the effectiveness of the cleaning (21). This effect, however, was not observed in this study since no significant differences between groups were observed when the apical thirds were compared.

Physical properties were believed to influence the action of the irrigants during PUI (9). Root canal filling remnants were observed in all groups. However, the lower scores attributed to the use of formamide alone compared with the use of ultrasound activation, although not statistically significant, may suggest that PUI with Endosolv $\mathrm{R}$ removed more residues from root canal walls than the undisturbed solvent. As no similar behavior was observed when distilled water was used without and with ultrasound activation, it could be hypothesized that, besides acoustic microstreaming, the chemical action of the irrigant might be important for residue removal from canal walls, isthmuses or reentrances. Complying with this assumption, the removal of the smear layer with PUI was significantly better when EDTA and sodium hypochlorite were employed in primary treatment relative to distilled water (9).

Ultrasound energy was applied at maximum intensity for only $60 \mathrm{~s}$, based on the effectiveness for dentin debris removal as described by Sabins et al (22). Considering the apical thirds of root canal walls from each group

\begin{tabular}{lccccc}
\hline Groups & Coronal & Middle & Apical & Total & p value* \\
\hline Endosolv R+US & $1.50(1-4) \mathrm{a}$ & $2.00(2-4) \mathrm{a}$ & $1.00(1-3) \mathrm{a}$ & $1.50(1-4) \mathrm{b}$ & 0.580 \\
H2O+US & $2.00(1-4) \mathrm{a}$ & $1.00(1-3) \mathrm{a}$ & $2.50(1-4) \mathrm{a}$ & $2.00(1-4) \mathrm{b}$ & 0.440 \\
Endosolv R & $3.00(1-4) \mathrm{a}$ & $2.50(1-4) \mathrm{a}$ & $4.00(3-4) \mathrm{a}$ & $3.00(1-4) \mathrm{b}$ & 0.150 \\
$\mathrm{H} 20$ & $4.00(2-4) \mathrm{a}$ & $3.00(1-4) \mathrm{a}$ & $3.00(1-4) \mathrm{a}$ & $3.50(1-4) \mathrm{b}$ & 0.897 \\
\hline
\end{tabular}

Same letters indicate no statistically significant differences at 5\% significance level. 

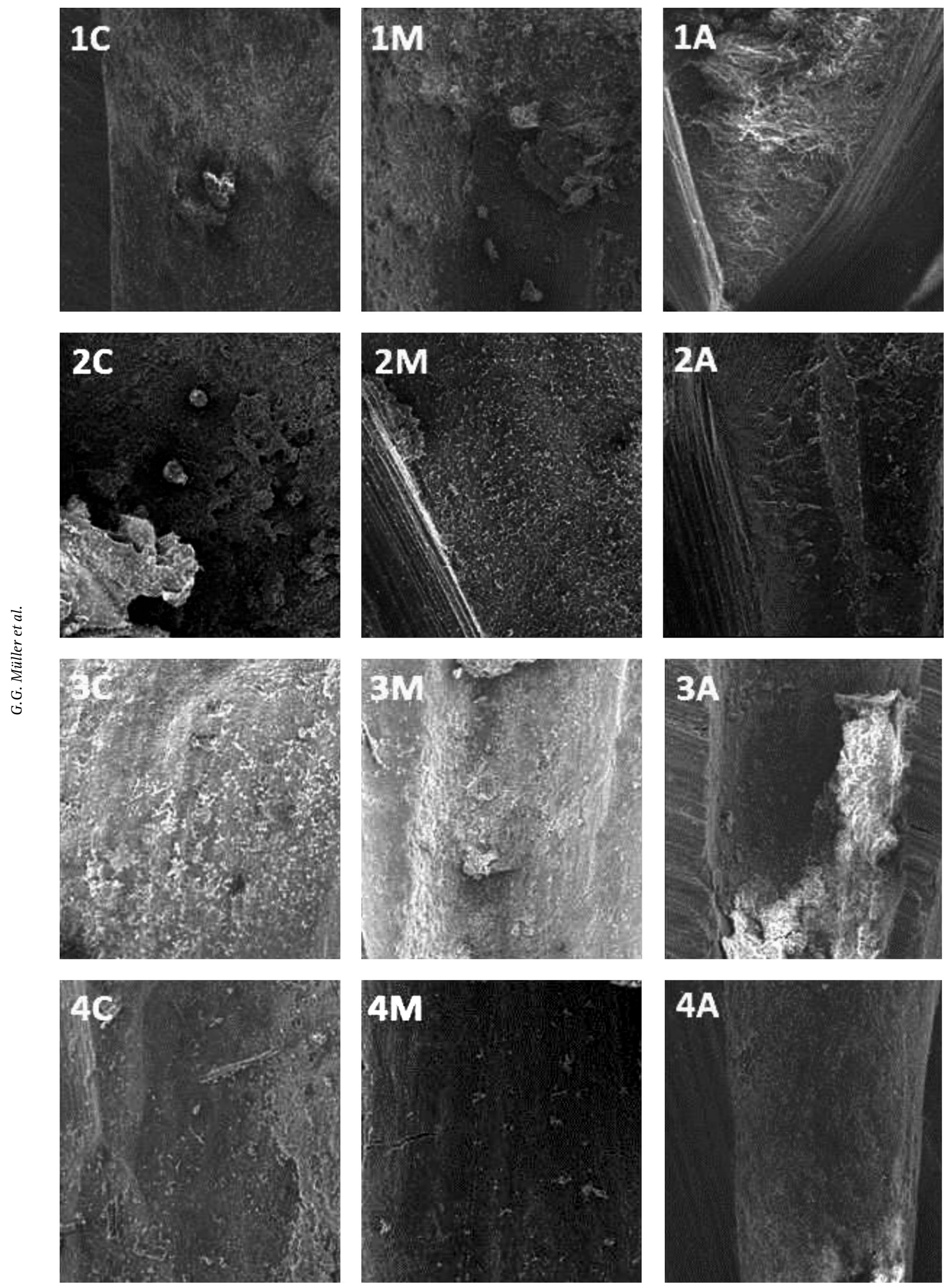

Figure 1. SEM micrographs of root canal surfaces after final flush treatments. Numbers indicate the groups whereas letters indicate the root canal thirds (C: coronal, M: middle, A: apical). 
differences in composition and structure between artificial smear layer and AH Plus/gutta-percha remnants produced in this study, the time interval adopted was insufficient to dislodge the filling residues from the root canal walls of extracted teeth, and different cleaning effects could be expected if longer time intervals were used.

At first, some chemical dissolution of filling residues by the organic solvent was expected, followed by elimination of these particles and renewal of the solvent solution due to ultrasound micro-streaming and cavitation effects. Although some chemical dissolution of the residual sealer might have occurred, it was not sufficient to generate cleaner root canal walls. Nevertheless, most of the filling consisted of gutta-percha, whose susceptibility to Endosolv $\mathrm{R}$ may not be as significant as that detected in vitro for $\mathrm{AH}$ Plus (14). In addition, the solvent was not renewed in root canals, as usually performed in hand filling removal (22) and thus chemical action may have been limited.

Passive ultrasonic irrigation does not increase the apical extrusion of $\mathrm{NaOCl}$ (12). However, the main component of Endosolv $\mathrm{R}$ is formamide, a toxic substance in animal and human cells (24). Thus, additional testing with alternative non-toxic solvents is encouraged.

The type of sealer seemed to influence the amount of filling residues that remain after root canal retreatment with ProTaper Universal Retreatment instruments (5) as well as the chemical agent used for removal of AH Plus residues from dentin walls (25). Therefore, different results could be expected if other filling materials or organic solvents were tested.

In conclusion, the results of this in vitro study showed that PUI with Endosolv R or distilled water was not effective in filling debris removal from root canal walls. Meanwhile, the supplementary enlargement of root canals with NiTi rotary or precurved hand instruments to achieve some reduction of filling remnants during retreatment is still recommended.

\section{Resumo}

0 objetivo deste estudo foi investigar se a irrigação final com o solvente Endosolv $\mathrm{R}^{\circledast}$ e ultrassom promovia maior limpeza nas paredes do canal radicular durante o retratamento endodôntico. Um total de 56 dentes pré-molares extraidos foram instrumentados manualmente utilizandose a técnica escalonada e obturados com guta-percha e cimento $\mathrm{AH}$ Plus. Após nove meses, os canais foram retratados através da remoção da guta-percha e do cimento com Protaper Universal Retratamento e preparo rotatório com Sistema Protaper Universal até o instrumento F5. Após essa etapa, a amostra foi aleatoriamente dividida em quatro grupos $(n=14)$ e os dentes submetidos à irrigação ultrassônica passiva (PUI) associada ao solvente Endosolv $\mathrm{R}$ ou à água destilada. Nos grupos controle, os irrigantes permaneceram sem agitação. Em seguida as raizes foram clivadas e examinadas sob microscopia eletrônica de varredura (MEV) para que a quantidade de material obturador remanescente nas paredes do canal fosse avaliada por dois examinadores treinados de forma cega. Os dados foram analisados através dos testes de Kruskal-Wallis e de Student-Newman-Keuls post hoc $(\alpha=0.05)$. Todos os grupos apresentaram residuos de materiais obturadores nos três terços do canal radicular após o retratamento. Não houve diferenças significativas entre os grupos ou entre os terços dos canais em cada um dos grupos $(p>0,05)$. Concluiu-se que PUI com Endosolv R não foi efetiva para a remoção de remanescentes de material obturador das paredes do canal radicular.

\section{Acknowledgements}

The authors wish to acknowledge Pró-Reitoria de Pesquisa - UFRGS for funding and Electron Microscopy Center (CME) - UFRGS team for their support.

\section{References}

1. Alves FR, Almeida BM, Neves MA, Moreno JO, Rôças IN, Siqueira-Júnior JF. Disinfecting oval-shaped root canals: effectiveness of different supplementary approaches. J Endod 2011;37:496-501.

2. Orstavik D, Haapasalo M. Disinfection by endodontic irrigants and dressings of experimentally infected dentinal tubules. Endod Dent Traumatol 1990;6:142-149.

3. Zmener O, Pameijer CH, Banegas G. Retreatment efficacy of hand versus automated instrumentation in oval-shaped root canals: an ex vivo study. Int Endod J 2006;39:521-526.

4. Marques da Silva B, Baratto-Filho F, Leonardi DP, Henrique Borges A, Volpato L, Branco Barletta F. Effectiveness of ProTaper, D-RaCe, and Mtwo retreatment files with and without supplementary instruments in the removal of root canal filling material. Int Endod J 2012;45:927932.

5. Só MVR, Saran C, Magro ML, Vier-Pelisser FV, Munhoz M. Efficacy of ProTaper retreatment system in root canals filled with gutta-percha and two endodontic sealers. J Endod 2008;34:1223-1225.

6. Tasdemir T, Yildirim T, Celik D. Comparative study of removal of current endodontic fillings. J Endod 2008;34:326-329.

7. Somma F, Cammarota G, Plotino G, Grande NM, Pameijer CH. The effectiveness of manual and mechanical instrumentation for the retreatment of three different root canal filling materials. J Endod 2008;34:466-469.

8. Só MV, De Figueiredo JA, Fachin EV, Húngaro Duarte MA, Pereira JR, Kuga MC, et al.. Clinical microscopic analysis of Protaper retreatment system efficacy considering root canal thirds using three endodontic sealers. Microsc Res Tech 2012;75:1233-1236.

9. Van der Sluis LW, Versluis M, Wu MK, Wesselink PR. Passive ultrasonic irrigation of the root canal: a review of the literature. Int Endod J 2007;40:415-426.

10. Moorer WR, Wesselink PR. Factors promoting the tissue dissolving capability of sodium hypochlorite. Int Endod J 1982;15:187-196.

11. Bodrumlu E, Er 0, Kayaoglu G. Solubility of root canal sealers with different organic solvents. Oral Surg Oral Med Oral Pathol Oral Radiol Endod 2008;106:e67-e69.

12. Tasdemir T, Er K, Celik D, Yildirim T. Effect of passive ultrasonic irrigation on apical extrusion of irrigating solution. Eur J Dent 2008;2:198-203.

13. Roberts S, Kim JR, Gu LS, Kim YK, Mitchell OM, Pashley DH, et al.. The efficacy of different sealer removal protocols on bonding of self-etching adhesives to AH Plus - contaminated dentin. J Endod 2009;35:563-567.

14. Schönhofen AP, Kopper PMP, Grecca FS, Luisi SB, Santos RB, Bodanezi, A. Dissolution of resin-based sealers by organic solvents over time. J Dent Res (Special Issue B) 2012;91:1051.

15. Marshall FJ, Pappin J. A crown-down pressureless preparation root canal enlargement technique. Technique manual. Portland 1980. Oregon Health Sciences University.

16. Van Meerbeek B, Vargas $M$, Inoue $S$, Yoshida Y, Perdigão J, Lambrechts $P$, et al.. Microscopy investigations. Techniques, results, limitations. Am J Dent 2000;13:3D-18D.

17. Kfir A, Tsesis I, Yakirevich E, Matalon S, Abramovitz I. The efficacy of five techniques for removing root filling material: microscopic versus radiographic evaluation. Int Endod J 2012;45:35-41.

18. Duarte MAH, Só MVR, Cimadon VB, Zucatto C, Vier-Pelisser FV, Kuga 
MK. Effectiveness of rotary or manual techniques for removing a 6-year-old filling material. Braz Dent J 2010;21:148-152.

19. Dall'Agnol C, Hartmann MS, Barletta FB. Computed tomography assessment of the efficiency of different techniques for removal of root canal filling material. Braz Dent J 2008;19:306-312.

20. Krell KV, Johnson RJ, Madison S. Irrigation patterns during ultrasonic canal instrumentation. Part I. K-Type Files. J Endod 1988;14:65-68.

21. Paragliola R, Franco V, Fabiani C, Mazzoni A, Nato F, Tay FR, et al.. Final rinse optimization: influence of different agitation protocols. J Endod 2010;36:282-285.

22. Oyama KON, Siqueira EL, Santos M. In vitro study of effect of solvent on root canal retreatment. Braz Dent J 2002;13:208-211.
23. Sabins RA, Johnson JD, Hellstein JW. A comparison of the cleaning efficacy of short-term sonic and ultrasonic passive irrigation after hand instrumentation in molar root canals. J Endod 2003;29:674-678.

24. Ivanov IT. Rapid method for comparing the cytotoxicity of organic solvents and their ability to destabilize proteins of the erythrocyte membrane. Pharmazie 2001;56:808-809.

25. Kuga MC, Faria G, Rossi MA, do Carmo Monteiro JC, Bonetti-Filho $\mathrm{I}$, Berbert FL, et al.. Persistence of epoxy-based sealer residues in dentin treated with different chemical removal protocols. Scanning 2013;35:17-21. 